\title{
Pengembangan Perangkat Pembelajaran Matematika REALISTIK UNTUK MEMBELAJARKAN KEMAMPUAN PEMECAHAN MASALAH MATEMATIKA SISWA SMP
}

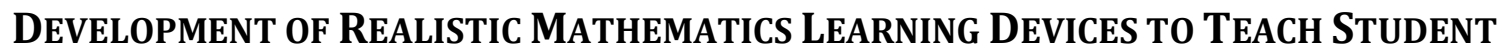 Problem Solving ABility MAThematics SMP}

\author{
Marzuki Ahmad1 dan Seri Asmaidah² \\ 1Pendidikan Matematika, STKIP Tapanuli Selatan \\ marzuki.ahmad45@yahoo.com \\ 2Pendidikan Fisika, STKIP Tapanuli Selatan \\ asmaidah_seri@yahoo.co.id
}

\begin{abstract}
Abstrak
Penelitian ini bertujuan untuk menghasilkan produk prangkat Pembelajaran Matematika Realistik (PMR) yang dapat membelajarkan kemampuan pemecahan masalah matematika siswa SMP. Perangkat pembelajaran yang dikembangkan meliputi Rencana Pelaksanaan Pembelajaran (RPP), Lembar Aktivitas Siswa (LAS), Buku Pegangan Guru (BPG) dan Buku Siswa (BS) pada materi himpunan untuk siswa kelas VII SMP. Selain itu dikembangkan Juga instrumen tes Kemampuan Pemecahan Masalah Matematika (KPMM). Jenis penelitian yang digunakan dalam penelitian ini adalah penelitian pengembangan (development research) dengan model 4D Thiagarajan, dkk. (1974) yang meliputi tahap pendefenisian (define), tahap perencanaan (design), tahap pengembangan (develop) dan tahap penyebaran (disseminate). Tahapan pengembangan yang dilakukan menerapkan ujicoba produk. Proses tahap pengembangan yang dilakukan melibatkan sampel penelitian yaitu siswa kelas VII SMP Negeri 2 Tambangan sebagai proses uji keterbacaan/simulasi dan siswa kelas VII SMP Negeri 1 Tambangan sebagai kelas ujicoba lapangan. Data dikumpulkan melalui dokumen dan tes. Penelitian yang dilakukan memberikan kesimpulan bahwa dihasilkan produk perangkat pembelajaran matematika realistik yang baik/valid untuk topik himpunan untuk siswa kelas VII SMP.

Kata Kunci: PMR, Pemcahan Masalah, Perangkat Pembelajaran.
\end{abstract}

\begin{abstract}
The aims of the study are to produce the Realistic Mathematics Education (RME) device to teach of students' problem solving ability on Mathematics to the Junior High School. Education device development consists of Lesson Plan, Students Activity sheet, Teachers' Book, and Students' Book on set matter to the seventh grade students. In the other hand, instrument of problem solving ability was developed. This study is research and development on Four-D Thiagarajan et.al (1974) consists of define, design, develop and disseminate. Steps of development consists test of product. The sample of study is the seventh grade students of SMP Negeri 2 Tambangan as the simulation test and the SMP Negeri 1 Tambangan as the test. The data is collected through document and test. The result of the study is produced the good and valid Realistic Mathematics Education (RME) device on set matter to teach the seventh grade students.

Keyword: RME, Problem Solving, Learning Device.
\end{abstract}

Jurnal "Mosharafa", Volume 6, Nomor 3, September 2017 


\section{Pendahuluan}

Kemampuan pemecahan masalah merupakan suatu keterampilan bermatematika yang sangat penting untuk dikuasai siswa. Menurut Dahar (1989:138), pemecahan masalah merupakan suatu kegiatan manusia yang menggabungkan konsep-konsep dan aturan-aturan yang telah diperoleh sebelumnya, tidak sebagai keterampilan generik. Dalam hal ini kemampuan pemecahan masalah yang dimiliki akan semakin meningkat apabila melakukan kegiatan pemecahan masalah terhadap masalah-masalah yang baru. Oleh karena itu, kemampuan pemecahan masalah perlu terus secara berkelanjutan dilatih sehingga seseorang itu mampu menjalani kehidupan yang senantiasa diiringi pertumbuhan masalah. Selanjutnya Sovhick (Saragih, 2007:53) menyatakan bahwa melalui latihan pemecahan masalah akan dapat menghasilkan individu-individu yang memiliki kompetensi bermatematika, karena memiliki manfaat yang besar bagi penanaman kompetensi matematika siswa.

Mengajarkan kemampuan pemecahan masalah kepada siswa merupakan kegiatan yang dilakukan oleh seoarang guru dimana guru membangkitkan siswa agar menerima dan merespon pertanyaan yang disampaikan dan membimbing siswa untuk sampai pada penyelesaian masalah. Proses pemecahan masalah yang dilakukan menurut Gagne (Ruseffendi, 1991: 169), terdapat 5 bagian, yaitu: (a)
Menyajikan masalah dalam bentuk yang lebih jelas; (b) Menyatakan masalah dalam bentuk yang dapat dipecahkan; (c) Menyusun hipotesis-hipotesis alternatif dan prosedur kerja yang diperkirakan baik untuk dipergunakan dalam memecahkan masalah (d) menguji hipotesis dan melakukan pemecahan untuk memperoleh hasilnya; (e) Memeriksa kembali apakah hasil yang diperoleh itu benar, atau mungkin memilih alternatif pemecahan yang terbaik.

Pemecahan masalah (problem solving) merupakan bagian penting dalam kegiatan pembelajaran. Menurut Wahyudin (2003), menngungkapkan 10 strategi problem solving yang dapat dijadikan dasar pendekatan mengajar, yaitu: (a) Bekerja mundur; (b) Menemukan suatu pola; (c) Mengambil suatu sudut pandangan yang berbeda; (d) Memecahkan suatu masalah yang beranalogi dengan masalah yang sedang dihadapi tetapi lebih sederhana; (e) Mempertimbangkan kasus-kasus ekstrim; (f) Membuat gambar (representasi visual); (g) Menduga dan menguji berdasarkan akal; (h) Memperhitungkan semua kemungkinan (daftar/pencantuman yang menyeluruh); (i) Mengorganisasikan data; (j) Penalaran logis.

Menurut Polya sebagaimana dikutif oleh Zulkarnaen dalam Afriansyah dan Nadhifah (2016:35), solusi soal pemecahan masalah memuat 4 tahapan penyelesaian, yaitu: (a) Memahami masalah; siswa dituntut untuk memahami permasalahan; (b) Membuat 
rencana pemecahan; siswa memikirkan dan mempertimbangkan rencana pemecahan yang harus dilakukan; (c) Menjalankan rencana pemecahan; siswa melaksanakan rencana pemecahan yang telah direncanakan kemudian memeriksa setiap langkah demi langkah dalam penyelesaian masalah (d) Memeriksa hasil pemecahan masalah; siswa menguji langakah-langkah yang telah dilakukan.

Mengukur kemampuan pemecahan masalah siswa dapat dilakukan melalui pemberian tes kemampuan pemecahan masalah. Gredler, (2011:285) menyatakan bahwa pemecahan masalah secara umum meliputi tiga langkah, (i) penyajian masalah, (ii) menentukan tujuan dan subtujuan dan mulai memecahkan masalah untuk untuk subtujuan, (iii) menilai perbedaan antara keadaan sekarang dan keadaan yang diinginkan, mencari cara-cara yang tepat untuk mereduksi perbedaan dan mengevaluasi hasil (analisis means-ends).

Dewasa ini, pelaksanaan pembelajaran yang terjadi cendrung bersifat konvensional. Pembelajaran yang terjadi masih didominasi oleh aktivitas guru. Menurut Soejadi (Trianto, 2012:18) menyatakan bahwa dalam kurikulum sekolah di Indonesia terutama pada pelajaran eksak (matematika, fisika, kimia) selama ini terpatri pada kebiasaan dengan urutan sajian pembelajaran (1) diajarkan teori, Teorema, defenisi (2) diberikan contoh-contoh dan diberikan latihan dan soal-soal. Kegiatan pembelajaran yang kurang merangsang aktivitas siswa akan berpengaruh pada menurunnya kualitas pembelajaran. Selanjutnya Murniaty, dkk, (2013:115) mengemukakan bahwa proses pembelajaran di kelas selama ini masih didominasi guru dan guru belum mengembangkan strategi pembelajaran matematika yang sesuai untuk mengatasi permasalahan tersebut.

Wahyudin (2008:2) menjelaskan anak anak belajar melalui berbuat (doing) sehingga memerlukan banyak pengalaman langsung dalam memanifulasi, mengkaji, mendiskuisikan dan berbagi ide-ide matematis. Dengan demikian siswa akan lebih terlatih untuk selalu mengembangkan kompetensi bermatematikanya. Pendekatan Pembelajaran Matematika Realistik (PMR) merupakan pendekatan dalam pembelajaran matematika yang memandang matematika merupakan aktivitas bagi manusia dan memberikan penekanan pada kebermaknaan konsep matematika. Dalam PMR Siswa dituntut berpikir tentang suatu persoalan yang dekat dengan dunia nyata dan mencari sendiri cara pemecahannya dengan bantuan guru melalui proses scaffolding.

Gravemeijer (1994:90-91) menyatakan bahwa PMR merupakan aktivitas manusia, yang dikembangkan dengan prinsif dasar, yaitu (1) Guided Reinvention and Progressive Mathematization (Penemuan Terbimbing dan Bermatematika secara Progresif; (2) Didactical Phenomenology (Penomena dalam Pembelajaran; dan (3) Selfdeveloped Models (Pengembangan 
Model Secara Mandiri). Selnjutnya karakteristik PMR menurut Treffers dalam Wijaya (2012:21-23) yaitu: (1) Penggunaan konteks dalam pembelajaran, (2) Penggunaan model untuk mengembangkan matematisasi progressif, (3) Pemampaatan hasil kontruksi siswa, (4) Terjadi Intraktivitas guru dan siswa, (5) Keterkaitan materimateri matematika.

Memperhatikan prinsif dan karakteristik dari PMR maka dalam pelaksanaan PMR menggunakan konteks (masalah dunia nyata) titik awal untuk membangun suatu konsep pelajaran. Konteks diberikan kepada siswa dengan tujuan siswa menemukan kembali (reinvent) idedan konsep matematika dengan bimbingan guru. Dengan adanya pemberian konteks, siswa akan menerjemahkan masalah dunia nyata kedalam bentuk model matematika (matematisasi). Wijaya, A. (2012:42) menyatakan matematisasi dalam PMR melibatkan generalisasi (generalizing) dan formalisasi (formalizing). Kedua aspek ini juga dikenal dengan matematisasi horizontal dan matematisasi vertikal yang pada akhir prosesnya diperoleh model formal matematika. Proses pengembangan konsep dan ide-ide matematika yang dimulai dari dunia nyata oleh Berikut dibawah ini digambarkan Matematisasi Konseptual De Lange (1987:72).

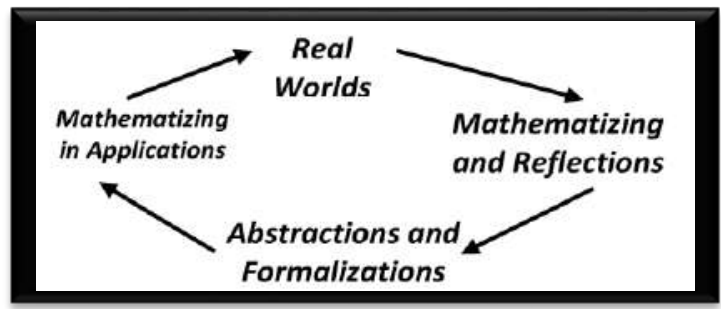

Gambar 1. Matematisasi Konseptual.

Pelaksanaan PMR terjadi interaktifitas antara guru dan siswa. Interktifitas yang terjadi meliputi interaksi antara siswa dengan siswa dan siswa dengan guru.Dengan adanya interaksi antara siswa dalam belajar guru memberikan memberikan arahan kepada siswa dalam mengaitkan materi materi pelajaran. Pengaitan materi diberi kebebasan dengan berkerjasaman yang pada ahirnya diperoleh kesimpulan. Johnson (2011:116) menyatakan setiap pelajaran yang dihubungkan memberikan konteks pelajaran yang kaya, meskipun tujuan, penilaian dan nilai akhir yang terpisah.

Hasil penelitian Murniaty, dkk. (2013) menunjukkan bahwa perangkat pembelajaran matematika realistik tergolong kriteria baik yang telah memenuhi persyaratan validitas dan kepraktisan. Implementasi perangkat pembelajaran matematika realistik juga efektif dalam meningkatkankemampuan pemecahan masalah siswa SMP sebagai subjek coba. Hasil penelitian Muchlis, (2012) menunjukkan bahwa kemampuan pemecahan masalah matematika siswa yang belajar dengan pendekatan PMRI lebih baik secara signifikan dari pada siswa yang belajar dengan pendekatan 


\begin{tabular}{|c|c|}
\hline $\begin{array}{l}\text { onvensional, terjadi perkembangan } \\
\text { emampuan pemecahan masalah } \\
\text { tunjukkan dengan kemampuan siswa } \\
\text { enyelesaikan soal-soal yang tidak rutin. } \\
\text { elanjutnya penelitian Sugiman dan }\end{array}$ & $\begin{array}{l}\text { kemampuan pemecahan masalah } \\
\text { matematis siswa?" dengan tujuan dari } \\
\text { penelitian adalah untuk menghasilkan } \\
\text { produk prangkat pembelajaran } \\
\text { matematika realistik dan isntrumen tes }\end{array}$ \\
\hline Imah, (2010) diperoleh bahwa & ampuan pemecahan \\
\hline
\end{tabular}

masalah matematis siswa dengan PMR lebih tinggi daripada peningkatan kemampuan pemecahan masalah matematis siswa PB pada keseluruhan siswa dan semua level sekolah.

Perangkat pembelajaran yang mendukung pada pelaksanaan pembelajaran matematika realistik masih masih sangat kurang. Dimana sebagian besar buku-buku yang digunakan selama ini menekankan pada pengertian, rumus dan contoh-contoh. Soal-soal yang dijadikan latiahan siswa bukan merupakan masalah yang dekat dengan kehidupan nyata siswa. Interaktifitas siswa dalam pembejaran masih sangat kurang. Demikian juga, kegiatan yang membimbing siswa dalam melakukan aktivitas pembelajaran kurang tersedia. Sebagai upaya meningkatkan kemampuan pemecahan masalah, penting dilakukan pengembangan perangkat pembelajaran yang sesuai dengan pendekatan pembelajaran matematika realistik.

Dari uraian sebelumnya peneliti merumuskan masalah "Bagaimana validitas perangkat pembelajaran melalui pendekatan PMR untuk meningkatkan

\section{Metode}

Penelitian ini merupakan penelitian pengembangan perangkat pembelajaran model 4-D Thiagarajan, dkk. (Trianto, 2011:189) model ini terdiri dari 4 tahap pengembangan yaitu tahap pendefenisian (define), tahap perencanaan (design), tahap pengembangan (develop) dan tahap penyebaran (disseminate). Alur procedural tahapan pengembangan dapat dilihat pada gambar dibawah ini.

Perangkat pembelajaran yang dikembangkan dalam penelitian ini adalah perangkat pembelajaran dengan Pendekatan Pembelajaran Matematika Realistik (PMR) pada materi himpunan di tingkat SMP. Perangkat pembelajaran yang dimaksud adalah Rencana Pelaksanaan Pembelajaran (RPP), Lembar Aktivitas Siswa (LAS), Buku Pegangan Guru (BPG) dan Buku Siswa (BS) pada materi himpunan untuk siswa tingkat Sekolah Menengah Pertama (SMP). Penelitian pengembangan dilakukan dengan menggunakan Modifikasi model pengembangan 4D. 


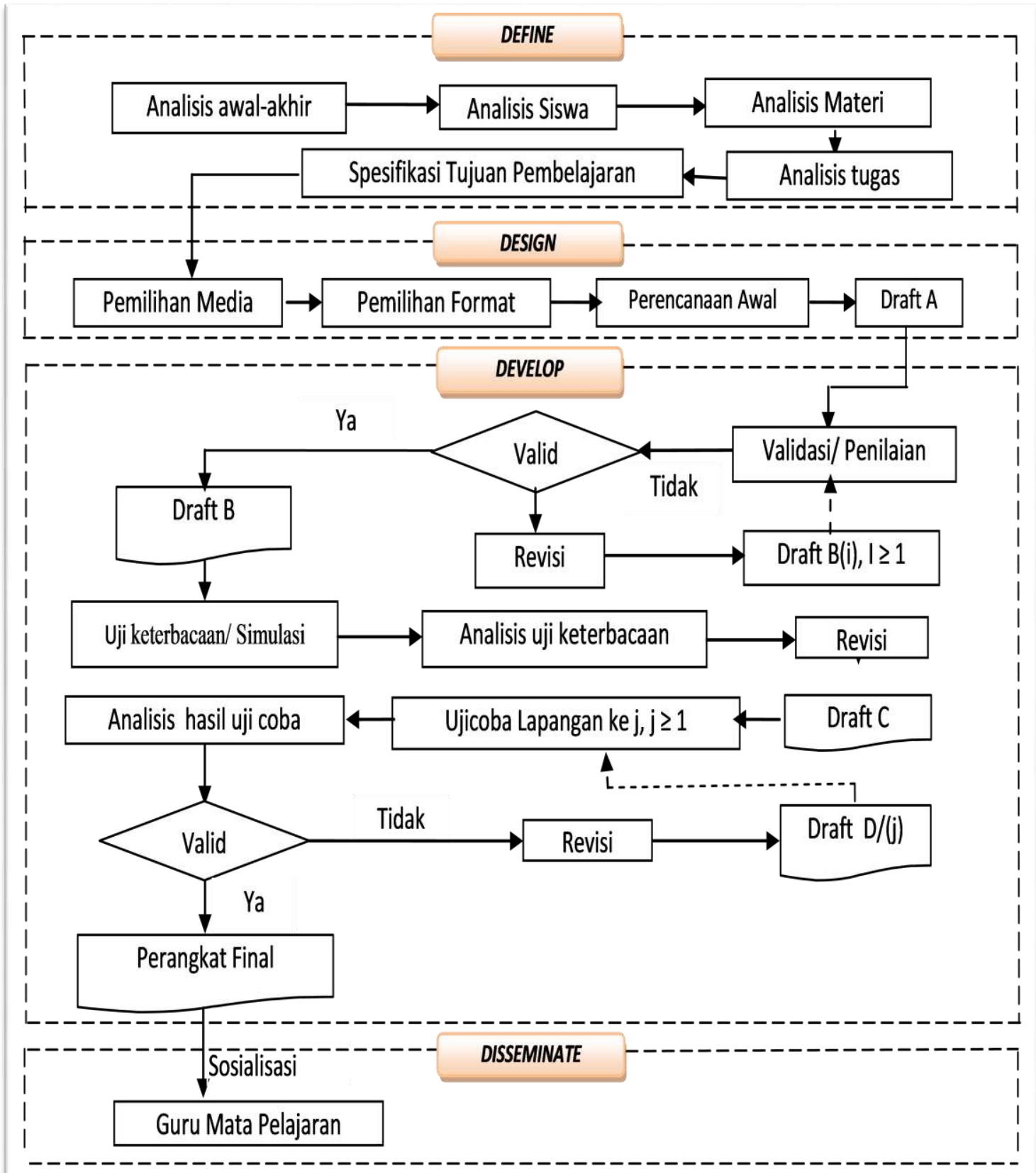

Gambar 1.1. Modifikasi Model 4D

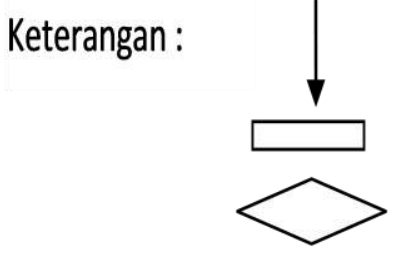

: garis pelaksanaan

$\longrightarrow \quad$ :garis siklus

: jenis kegiatan

: hasil kegiatan

: pengambilan keputusan

Gambar 2. Modifikasi model pengembangan 4D. 


\section{HASIL dAN PEMBahasan}

Pengembangan

perangkat

pembelajaran diawali dengan validasi perangkat pembelajaran dan instrument penelitian kepada validator yang dianggap memiliki kompetensi memberikan saran dan penilaian terhadap perangkat pembelajaran dan instumen yang diperlukan. selanjutnya dilakukan ujicoba perangkat yang meliputi tahapan uji keterbacaan/simulasi dan Uji coba lapangan. Uji keterbacaan/simulasi dilaksanakan pada siswa kelas VII-2 SMP Negeri 2 Tambangan, kemudian dilaksanakan simulasi pada kelas VII-3 SMP Negeri 2 Tambangan. Dan dilanjutkan tahap ujicoba lapangan di SMP Negeri 1 Tambangan kelas VII-1 sebagai kelas kontrol dan kelas VII-2 sebagai Kelas Eksperimen.

\section{A. Validasi perangkat pembelajaran oleh validator}

Draft perangkat pembelajaran yang dihasilkan divalidasi oleh validator (validasi ahli). Validasi para ahli difokuskan pada format, isi, ilustrasi, dan bahasa yang mencakup semua perangkat pembelajaran yang dikembangkan. Hasil validasi ahli berupa koreksi, kritik, dan saran digunakan sebagai dasar untuk melakukan revisi dan penyempurnaan terhadap perangkat pembelajaran. Maka perangkat pembelajaran telah dinyatakan valid oleh validator. Dapat dilihat dari hasil validasi validator:

- Rencana Pelaksana Pembelajaran (RPP)
Rencana pelaksana pembelajaran (RPP) terdiri 5 set untuk 5 kali pertemuan. Validasi kelima RPP tersebut secara garis besar dijabarkan sebagai berikut: Hasil kelima orang validator memberikan penilaian 3 ke atas, berarti komponenkomponen dalam rencana pelaksana pembelajaran mendapatkan penilaian baik. Rata-rata total 4,26. Hasil validasi rencana pelaksana pembelajaran adalah "baik".

- Lembar Aktivitas Siswa (LAS)

Kelima orang validator memberikan penilaian 3 ke atas, berarti komponenkomponen dalam LAS mendapat penilaian cukup baik, baik, dan sangat baik. Ratarata total 4,30. Kelima validator menyimpulkan bahwa LAS "baik".

- Buku siswa

Dapat dilihat bahwa lima orang validator memberikan penilaian 3 ke atas, berarti komponen-komponen dalam buku siswa mendapatkan penilaian cukup baik, baik, dan sangat baik. Rata-rata total 4,23. Kelima orang validator menyimpulkan bahwa buku siswa baik.

- Buku Guru

Kelima validator memberikan penilaian 3 ke atas. berarti komponen-komponen dalam buku guru mendapatkan penilaian baik. Rata-rata total 4,22. Kelima orang validator menyimpulkan bahwa buku guru "baik".

\section{B. Uji Keterbacaan/Simulasi}

Tahapan ini meliputi proses uji keterbacaan terhadap perangkat pembelajaran dan instrument penelitian 
secara sederhana dan porses validasi instumen tes KPMM siswa.

Proses uji keterbacaan merupakan proses melihat keterbacaan siswa terhadap perangkat pembelajaran dan instumen penelitian. Dimana melalui uji pretes dan penerapan perangkat pembelajaran matematika realistik dengan pelaksanaan pembelajaran sebanyak 5 kali diperoleh informasi bahwa perangkat pembelajaran dan instrument yang di uji dapat dipahami siswa dalam artian produk yang akan dikembangkan dapat dilanjutkan ketahapan berikutnya.

Tes KPMM siswa dilakukan ujicoba berbentuk soal uraian yang terdiri dari 8 butir yaitu nomor 1, 2, 3, 4, 5, 6, 7, 8 . Kelima validator yang memvalidasi instumen tes KPMM memberikan penilaian terhadap komponen-komponen dalam tes KPMM dengan penilaian valid, untuk validitas isi, jelas untuk validitas kejelasan petunjuk/tujuan, dan dapat dipahami untuk validitas bahasa. Validator memberi simpulan intrumen tes KPMM yang dibuat memenuhi validitas. Selanjutnya ujicoba intrumen penelitian memberikan hasil bahwa dari 8 butir soal yang diuji cobakan terdapat 5 soal yang valid dan dijadikan sebagai butir soal tes yang diterapkan pada ujicoba lapangan. Analisis validitas dilakukan dengan menentukan nilai korelasi dari butir soal dengan berbantuan SPSS 20 untuk soal pretes adalah pada tabel 1 berikut:

Tabel 1.

Nilai korelasi butir soal pretes KPMM

\begin{tabular}{ccccccccc}
\hline Keterangan & 1 & 2 & 3 & 4 & 5 & 6 & 7 & 8 \\
\hline$r_{x y}$ & 0.82 & 0.46 & 0.50 & 0.68 & 0.52 & 0,72 & 0,43 & 0,52
\end{tabular}

Validitas butir soal dengan $\mathrm{N}=24$ dan $\alpha=0,05$ maka $=r_{\text {tabel }}=0,404$ maka kedelapan soal yang diujikan adalah valid. Selanjutnya dilakukan analisis reliabilitas diperoleh koefisien reliabilitas 0,737 sehingga indeks reliabilitas tes berada pada kategori baik.

Tabel Analisis nilai korelasi dari butir soal postes KPMM dapat dilihat pada tabel 2 berikut:

Tabel 2.

Nilai korelasi butir soal postes KPMM

\begin{tabular}{cccccccccc}
\hline Keterangan & 1 & 2 & 3 & 4 & 5 & 6 & 7 & 8 \\
\hline$r_{x y}$ & 0.81 & 0.64 & 0.54 & 0.33 & 0.52 & 0,48 & 0,02 & 0,80
\end{tabular}

Berdasarkan tabel korelasi dengan $\mathrm{N}=24$ dan $\alpha=0,05$ maka $=r_{\text {tabel }}=$ 0,404 maka butir soal yang valid adalah butir soal no. 1, 2, 3, 5, 6, 8 valid. Selanjutnya dilakukan analisis reliabilitas tes dengan diperoleh koefisien reliabilitas
0,744 sehingga reliabilitas tes berada dalam interpretasi baik nilai indeks sensitifitas antara butir soal pretes dan postes 0,38 atau berada dalam kategori sensitivitas sedang. 


\section{Uji Coba Lapangan}

Ujicoba yang dilaksanakan melibatkan siswa kelas VII-2 SMP Negeri 1 Tambangan yang siswanya berjumlah 24 orang dijadikan sebagai kelas eksperimen, selanjutnya kelas VII-1 SMP Negeri 1 Tambangan jumlah siswanya 26 orang dijadikan sebagai kelas kontrol yang. Dalam ujicoba yang dilakukan diperoleh data ketuntasan belajar siswa.

Pelaksanaan Pembelajaran yang dilaksanakan melibatkan seorang observer yang membarikan penilaian terdapat aktivitas aktiv siswa pada kelompok sampel. Kelompok sampel terdiri dari 5 orang dimana melalui pengamatan yang dilakukan observer dari 10 kegiatan siswa yang diamati dari pertemuan pertama sampai kelima keseluruhan aspek yang diamati memnuhi kriteria keefektifan. Selanjutnya respon siswa terhadap pembelajaran yang diperoleh melalui pemberian lembar angket siswa setelah siswa mengikuti PMR diperoleh data Pendapat siswa terhadap komponen pembelajaran yang terdiri dari buku siswa, lembar kegiatan siswa, dan tes kemampuan pemecahan masalah matematika siswa berada di atas $80 \%$ yaitu $95,83 \%$. Artinya setiap aspek yang terdapat pada pembelajaran direspon positif oleh siswa sehingga perangkat pembelajaran tidak mengalami revisi berdasarkan respon positif siswa.

Ketuntasan belajar siswa dapat dilihat pada tabel 3 dimana pada kelas eksperimen yaitu terdapat 22 siswa dari 24 siswa yang tuntas dalam kegiatan pembelajaran sementara 2 orang tidak tuntas dengan KKM sebesar 76 (KKM pelajaran matematika SMP Negeri 1 Tambangan). Selanjutnya pada kelas kontrol terdapat 21 siswa dari 26 siswa yang masuk pada kategori tuntas dan 5 orang tidak tuntas. Dengan demikian ketuntasan belajar siswa pada kelas eksperimen lebih baik dari pada kelas kontrol. Ditinjau dari capaian tujuan pembelajaran dimana ketuntasan klasikal yang diperoleh pada kelas eksperimen yaitu sebesar 91,67\% sedangkan pada kelas kontrol yaitu $80,77 \%$ maka ketuntasan tujuan pembelajaran pada kelas eksperimen terpenuhi (Ketuntasan Klasikal Sekolah 85\%), sementara ketuntasan tujuan pembelajaran pada kelas kontrol tidak terpenuhi. Dengan demikian ketuntasan tujuan pembelajaran kelas eksperimen lebih baik dari pada kelas kontrol.

Tabel 3.

Hasil Pretes dan Postes KPMM

\begin{tabular}{|llllll}
\hline \multirow{2}{*}{ Ketuntasan } & \multicolumn{3}{c}{ Kelas Eksperimen } & \multicolumn{2}{c}{ Kelas Kontrol } \\
\cline { 2 - 6 } & \multicolumn{3}{c}{ Posttest } & \multicolumn{2}{c}{ Posttest } \\
\cline { 2 - 6 } & \multicolumn{2}{c}{ Jlh } & Persentase & Jlh & Persentase \\
\hline Tuntas & 22 & 91.67 & 21 & 80.77 \\
\hline Tidak Tuntas & 2 & 8.33 & 5 & 19.23 \\
\hline
\end{tabular}


Dari pembahasan hasil penelitian yang dilakukan jika ditinjau dari validitas yaitu terkait dengan validitas produk, kepraktisan yaitu respon dan kriteria perolehan aktivitas siswa dan efektifitas yang meliputi ketuntasan perolehan siswa dan ketuntasan capaian siswa secara klasikal maka dapat disimpulkan bahwa produk perangkat pembelajaran matematika realistik untuk membelajarkan kemampuan pemecahan masalah siswa memenuhi kriteria validitas produk.

\section{Penutup}

Berdasarkan pengembangan perangkat pembelajaran dengan menggunakan model 4-D yang telah dimodivikasi, dihasilkan produk perangkat pembelajaran matematika realistik yang baik/valid untuk topik himpunan. Perangkat pembelajaran tersebut terdiri dari: (1) Rencana Perangkat Pembelajaran (RPP), (2) Buku Guru (BG), (3) Buku Siswa (BS), (4) Lembar Aktivitas Siswa (LAS). Selanjutnya diperoleh juga instrument tes kemampuan pemecahan masalah matematika yang teruji validitas, reliabilitas dan sensitivitasnya.

Berdasarkan hasil penelitian ini, pembelajaran matematika realistik yang diterapkan pada kegiatan belajar mengajar di SMP Negeri 1 Tambangan memberikan beberapa hal yang penting untuk diperhatikan. Untuk itu peneliti menyarankan beberapa hal berikut. (1) Perangkat pembelajaran yang dihasilkan masih perlu diujicobakan di sekolahsekolah lain dengan berbagai kondisi agar diperoleh perangkat pembelajaran yang benar-benar berkualitas (sebagai tahapan penyebaran dalam model pengembangan 4- D). (2) Perlu dikembangkan perangkat pembelajaran matematika realistik untuk topik-topik yang lain agar perangkat pembelajaran matematika realistik lebih kaya dan bervasiasi.

\section{Daftar Pustaka}

Afriansyah, E. A. dan Nadhifah, G. (2016). Peningkatan Kemampuan Pemecahan Masalah Matematis Siswa dengan Menerapkan Model Pembelajaran Problem Based Learning dan Inquiry. Jurnal Mosharafa, Vol. 7, No. 1. Tersedia: $\quad$ http://jurnalmtk.stkipgarut.ac.id/data/edisi7/vol1/Ekasatya. pdf [3 Mei 2017].

Dahar, R.W. (1989). Teori-Teori Belajar. Jakarta: Erlangga.

Gravemeijer, K. (1994). Developing Realistic Mathematics Education. Utrecht: CD- $\beta$ Press.

Gredler, M.E. (2011). Learning and InstructionTeori dan Aplikasi. Jakarta: Kencana.

Johnson, E.B. (2011). Contextual Teaching and Learning. Bandung: Kaifa.

De Lange, J. (1987). Mathematics Insight and Meaning. Utrecht: OW \& OC.

Muchlis, E.E. (2012). Pengaruh Pendekatan Pendidikan Matematika Realistik Indonesia (PMRI) terhadap Perkembangan Kemampuan Pemecahan Masalah Siswa Kelas II SD Kartika 1.10 Padang. Jurnal Exacta, Vol. X, No. 2, pp. 136-139. Tersedia: http://repository.unib.ac.id/519/1/08. \%20Effie\%20Efrida\%20Mukhlis.pdf [3 Mei 2016] 
Murniaty, L.D. dkk. (2013). Pengembangan Perangkat Pembelajaran Matematika Realistik Untuk Meningkatkan Kemampuan Pemecahan Masalah Siswa SMP. Jurnal Pendidikan dan Pengajaran, Jilid 46, No. 2, pp.114124.

Tersedia:

https://ejournal.undiksha.ac.id/index. php/JPP/article/view/2670/2254. [5 Mei 2016]

Ruseffendi. E.T. (1991). Pengantar Kepada Membantu Guru mengembangkan Kompetensinya dalam Pengajaran Matematika untuk Meningkatkan CBSA. Bandung: Tarsito.

Saragih, S. (2007). Mengembangkan Kemampuan Berpikir Logis Dan Komunikasi Matematik Siswa Sekolah Menengah Pertama Melalui Pendekatan Matematika Realistik. Disertasi SPs-UPI. Tidak Diterbitkan.

Sugiman dan Kusumah, Y.S. (2010). Dampak Pendidikan Matematika Realistik Terhadap Peningkatan Kemampuan Pemecahan Masalah Siswa SMP. Jurnal Indo MS. J.M.E. Vol. 1 No. 1, pp. 41-51. Tersedia: http://staff.uny.ac.id/sites/default/file s/131930135/2010a RME+PSO.pdf. [5 Mei 2016]

Sujana. (2005). Metode Statistika. Tarsito: Bandung.

Thiagarajan, S. dkk. (1974). Intructional development for training teachers of exceptional children: A sourcebook. Minnesota: Central for Innovation on Teaching the Handicaped.

Trianto, (2013). Mendesain Model Pembelajaran Inovatif-Progresif: Konsep, Landasan, dan Implementasinya pada Kurikulum
Tingkat Satuan Pendidikan (KTSP). Jakarta: Kencana.

Wahyudin. (2003). Peranan Problem Solving. Proceeding National Seminar on Science and Mathematics Education, the Role of IT/ICT in Supporting the Implementation of Competensy-Based Curriculum. Bandung: JICA-IMSTEP. (2008). Pembelajaran dan Model-Model Pembelajaran (Pelengkap Untuk meningkatkan Kompetensi Pedagogis Para Guru dan Calon guru Propesional. Jakarta: Ipa Abong.

Wijaya, A. (2012). Pendidikan Matematika Realistik Alternatif Pendekatan Pembelajaran Matematika.

Yogyakarta: Graha IImu.

\section{Riwayat Hidup PenUlis}

Marzuki Ahmad, S.Pd, M.Pd.

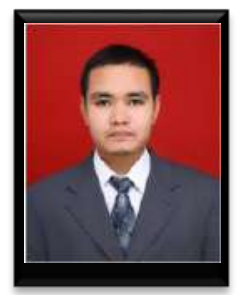

Lahir di Laru Lombang, 18 September 1988. Staf pengajar di STKIP Tapanuli Selatan. Studi S1 Pendidikan Matematika Universitas Islam Sumatera Utara, Medan, dan lulus tahun 2010; dan studi S2 Pendidikan Matematika Universitas Negeri Medan (Unimed) dan lulus tahun 2014.

Seri Asmaidah, S.Pd, M.Pd.

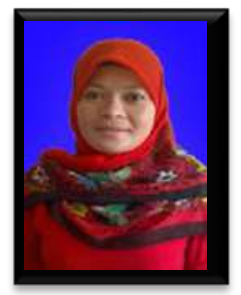

Lahir di Tapanuli Selatan, 7 Agustus 1985. Staf Pengajar di STKIP Tapanuli Selatan. Studi S1 Pendidikan Fisika Universitas Negeri Medan (Unimed), Medan, dan lulus tahun 2008; dan studi S2 Pendidikan Fisika Universitas Negeri Padang (UNP) dan lulus tahun 2012. 
This page is intentionally left blank 